\title{
Mathematics Learning Model of Open Problem Solving to Develop Students' Creativity
}

\author{
Ketut Suastika ${ }^{a}$ \\ aUniversity of Kanjuruhan Malang, INDONESIA
}

The purpose of this research is to produce an open problem solving mathematics learning model to help students develop their creativity which meets the criteria of validity, practicality, and effectiveness. The components of instruction model used adopt Joyce and Weil. The quality of the developed products was evaluated based on the product development evaluation developed by Neeven, which includes validity by validators, practicality, and the effectiveness of field experiment by observers. The syntax realization of model consisted of five phases, namely: (1) Introduction, (2) Concept tracking, (3) Open problem presentation, (4) Work presentation, and (5) Closing. The model that had been declared valid by the validator was then tested to see the practicality and effectiveness. The practicality and effectiveness of the model were obtained after three trials. In the third experiment, the criteria of practicality were achieved. The process of model development is based on the theory of development of Plomp, which consists of three phases, namely: (1) preliminary research, (2) prototyping phase, and (3) assessment phase. The development result of this study is an open problem solving math learning model that can develop students' creativity (PMT Model), which meets valid, practical, and effective criteria.

KEYWORDS

Development, Learning Model of open Problem Solving, Creativity
ARTICLE HISTORY

Received 15 September 2016 Revised 10 November 2016 Accepted 22 February 2017

\section{Introduction}

The process standard at the Education Unit Level Curriculum (KTSP) states that the learning process in each elementary and secondary education unit must be interactive, inspirational, fun, challenging and motivates learners to participate actively, and provide sufficient space for initiative, creativity and independence based on the talents, interests, and physical and psychological development of learners. The learning process listed in the KTSP process standard is still maintained at the standard of curriculum process 2013. It is written in Permendikbud no 65 of 2013 which the content is the same with that of KTSP process standard. Based on the description listed in the standard of process, it is clear that both KTSP and Curriculum 2013 emphasize the

\section{CORRESPONDENCE Ketut Suastika $\triangle$ suastika@unikama.ac.id}

(c) 2017 Ketut Suastika.

Open Access terms of the Creative Commons Attribution 4.0 International License apply. The license permits unrestricted use, distribution, and reproduction in any medium, on the condition that users give exact credit to the original author(s) and the source, provide a link to the Creative Commons license, and indicate if they made any changes. (http://creativecommons.org/licenses/by/4.0/) 
importance of learners' creativity development. This is worth considering because in the global era as today, life is full of competition in all fields. To be able to survive in this competitive era, individuals are required to have creativity.

In line with the demands of KTSP and Curriculum 2013, the demand for educational institutions to develop students' creativity is increasingly prominent. Nadjafikhah, et al. (2012) say that one goal of each educational unit is to encourage creative individuals who are able to develop the potential of their academic domain. Forrester (2008) says that all levels in education units should encourage the development of creative thinking abilities. The explanation of Wamendikbud of education in the implementation of Curriculum 2013 in Jakarta on January 14, 2014 declared that learning should support the development of students' creativity.

Emphasis on creativity development is also highly expected in learning in math classes. This can be seen from the opinion of Mann (2009) that learning mathematics without emphasis on creativity will deprive the opportunity to appreciate the beauty of mathematics, and fail to provide opportunities in developing the talent. In order for that students are able to build their mathematics talents, the mathematics teacher is required to develop the students' creativity in the learning that is done.

To develop creativity, Monahan (2002: 49) states "most people who study creativeness agree that problem solving is essential to creative achievement. Most who truly understand creativeness believe it's virtually impossible to be creative without a problem". Although problem-solving activities serve as a means to develop creative thinking skill, but not all types of problems have such potential. Pehkonen (2007), Stenberg (2006), and Nadjafikhah (2012) say that the kinds of problems that have the potential to develop students' creative thinking ability is an open issue. Therefore Leikin (in Kontoyianni, 2013) suggests a model for the assessment of creativity through the use of multiple solution of mathematical tasks. Hashimoto (1997) discusses that the openended approach is one aspect of fostering mathematical creativity. Sharp (2004) says teachers can make learners to behave creatively through: (1) tasks that do not only have one correct answer, (2) tolerating unique answers, (3) emphasizing the process not only the results.

Related to mathematics learning in the classroom, Siswono (2007) says mathematics learning process is still going on conventionally and tends to be mechanistic. It means that students listen, imitate or copy exactly the same way what the teacher gives without initiative. Students are not encouraged to develop their creativity. Izzati (2009) states that mathematics learning gives less attention to the development of high-level thinking skill such as the ability to think creatively and solving mathematical problems. In fact, these two capabilities are very important because in everyday life everyone always faces a variety of problems that must be solved and it demands creative thinking to find solutions to the problems faced. Based on these opinions, it is clear that the learning done by the teacher in the class still has not emphasized the development of the creativity of the students.

Meanwhile, the results of the current study of mathematical learning conditions are as follows. 
(1) Learning tends to be teacher centered.

More math teachers begin the learning process by discussing definitions, or simply presenting formulas related to a particular topic, followed by discussing examples of problems and ending by asking students to do exercises.

(2) Students are poorly trained in solving open problem that allow for many answers or different solutions.

In giving exercises, teachers only provide routine and closed type questions. The problem is also well formulated which has one correct answer for example, "Determine the area of the rectangle if the length is $5 \mathrm{~cm}$ and the width is $4 \mathrm{~cm}$ !" Such question is a matter of routine type because the problem can be solved immediately by using a routine procedure that has been mastered / understood by the students, namely counting $5 \times 4$ ". It is said "close" because the matter has one and only one correct answer namely $20 \mathrm{~cm}{ }^{2}$.

(3) Evaluation made emphasize more on mastery aspects of teaching materials, aspects related to students' mathematics creativity is almost never touched.

The following is given a sample of UKK of SMP grade VII. Figure 4.1 below shows that all UKK problems for grade VII are close.

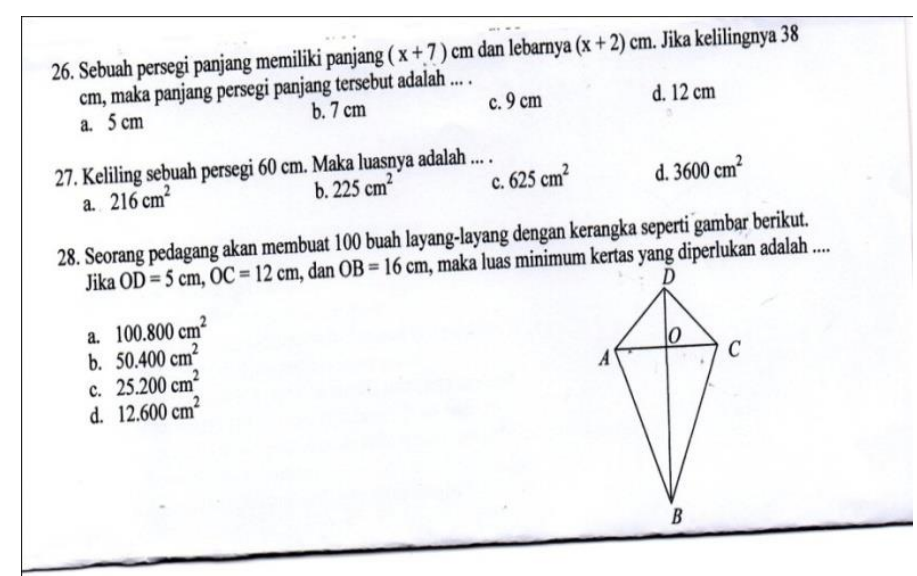

Figure 1. Sample of UKK SMP Problem

The learning done by the teacher has not contributed to the development of creativity, so has the textbook that students use as a handbook. Problems/tasks in junior mathematics books in general only routine problems which want one right answer. The questions / tasks related to determine the answers of more than one or more tasks that have a way of solving more than one are rarely found. The study conducted by the researcher on 4 (four) mathematics junior high schools books on perimeter topic and rectangular area showed the following results. Seen from the sample questions, 31 examples in the four books were examples of routine matters that required one answer. It meant open issues that required answers or more than one way of solving were not found. Seen from exercises: in book I, from the 41 questions, there was only one open issue; In book II, all 23 questions were routine questions that 
required one correct answer; In book III, all 26 questions were all about routine that required one right answer; And in book IV, from101 questions, there had been 5 (five) open problems that required answers or more than one way of completion. If presented, there were only $5 \%$ open issues in book IV. The existence of such learning resources certainly cannot encourage the development of students' mathematical creativity in the classroom.

Based on the above explanation, it is necessary to develop a learning model to develop students' creativity in an open problem solving.

\section{Method}

In this study, the stages of the research referred to the stages proposed by Plomp (2007), namely: (1) phase of preliminary research, (2) prototyping phase, and (3) assessment phase. To see the quality of the model that has been made, product quality assessment from Neeven (2007) was used. The three qualities seen from this product development were validity, practicality, and effectiveness of the model that had been created.

The validity of the product was determined by the validator. The product was said to be valid if it got a minimum score of 2.5. fulfilled:

The product was said to be practical, if the three following criteria were

(1) The product implementation was in high category ( $\mathrm{T} \geq 2.5)$

(2) The activity of students was minimally in active category $(\mathrm{X} \geq 2.5)$, and

(3) Class response was in positive category $(\bar{S} \geq 2)$.

The product was said to be effective, if:

(1) The average result of student learning classically was minimal (B $\geq$ 75 ), and at least $75 \%$ of students obtained score minimum 75

(2) The creativity of students classically was in the category minimum high $(\mathrm{Kr} \geq 2,25)$, and at least $75 \%$ of students creativity was in the high category

\section{Result}

The syntax realization of PMT model consisted of five phases, namely: (1) Introduction, (2) Concept tracking, (3) Open problem presentation, (4) Work presentation, and (5) Closing.

The model that had been realized then validated. After being declared valid, product trial was done.

\section{Validation Result}

There are two aspects measured in the model validation, namely the theoretical grounding aspect and the component component of the model. The prototype of the learning model that has been compiled is validated by three validators. The recap of model validation result is presented in Table 1.

Table 1. Recap of Model Validation Result 


\begin{tabular}{lccc}
\hline Aspect & Average of each Aspect & Average Total & Remark \\
\hline Theoretical Foundation & 3.10 & & \\
& & 3.21 & Valid \\
Model Components & 3.32 & & \\
\hline
\end{tabular}

\section{Product Trial Result}

The PMT model that had been declared valid by the validator was then tested to see the practicality and effectiveness. The practicality and effectiveness of the model were obtained after 3 (three) trials. Results of the first experiment show that the criteria of practicality and effectiveness had not yet been achieved because the students' activities and creativity were classically still low. In the second experiment, the criteria of practicality were achieved: (1) learning fulfilment was high; (2) the students were active; and (3) the students' response was positive. However, the criteria of effectiveness had not been achieved, because the percentage of students who belonged to high category still did not meet the expectation. In the third experiment, the criteria of practicality were achieved. The criteria of effectiveness were also obtained: (1) the students' learning outcome classically had met the criteria; (2) the students' creativity was also high; and (3) the percentage of students with high creativity had also fulfilled the criteria.

Recapitulation of product practical results for trial III can be seen in Table 2, while for product effectiveness for trial III can be seen in Table 3.

Table 2. Recap of Practicality Result of Trial Product III

\begin{tabular}{llll}
\hline No. & Aspect of Practicality & Average Score & Criteria \\
\hline 1 & Product implementation (T) & 3.25 & high \\
2 & Students' Activity (X) & 3.34 & active \\
3 & Students' Response (S) & 2.45 & positive \\
\hline
\end{tabular}

Table 3. Recap of Effectiveness Result of Trial Product III

\begin{tabular}{llll}
\hline No. & Effectiveness Aspect & Average Score & \% Of Students fulfilling Criteria \\
\hline 1 & Student Learning Outcomes (B) & 93.14 & $100 \%(\geq 75 \%)$ \\
2 & Students' Creativity (Kr) & 2.64 & $93 \%(\geq 75 \%)$ \\
\hline
\end{tabular}

\section{Discussion}

The discussion focuses on two things: (1) product trial and (2) the advantages of the PMT model.

\section{Product Trial}




\section{a. Model Implementation}

Overall, the average of model implementation on trial I was 2.91, which meant that according to predetermined criteria, the implementation of this model was in the high category. However, if it was examined more carefully for each teacher's activity for model implementation, actually only teacher's activity in introduction and closing phases were entirely categorized as high. In the concept tracking phase, open issues presentation phase, and work presentation phase, teacher's activity was mostly in low category since the average of its implementation was less than 2.5.

In this trial I, the teacher, in responding to students' difficulties when solving problems, mostly informed the answer to the problem being solved. The teacher should have provided sufficient assistance to the students who were experiencing difficulties, and the assistance provided in the process of solving the problem, students did not have to take over the problems that students were doing. It might happen because the habit of teacher who always provided answers to students when students could not solve a problem. Control of teacher was also lacking. This could be seen from the lack of teachers in reminding students to solve problems with more than one answer or more than one solution. In other words, the practicality of the model still did not meet the desired criteria. It meant a next trial was needed to be done. For subsequent trial, improvements were made. Improvements were focused on the aspect of applying of each phase, namely providing the teacher with guidance on the application of PMT model. The guidance was done after each meeting, considering the aspect that had the degree of implementation that had not met the criteria (aspects that were needed to be improved).

In the second trial, there had been an increase in the average score for teacher's activity in responding to students' questions, but the score was still less than 2.5. This indicated that there had been an increase in teacher in carrying out the principle of reaction but it was still not optimal. In other words, the practicality of the model still did not meet the desired criteria. It meant a next test was needed to be done. Because the cause of model implementation which was in low grade category in this second trial was still the same, improvements were also focused on providing guidance to the teacher in the implementation of PMT model. The guidance was done after each meeting, considering the aspect that had the degree of implementation that had not met the criteria (aspects that needed to be improved).

\section{b. Students' Activity}

The average of students' activity for all meetings of the trial result I was 2.47. It meant the students' activity for trial I was still in less active criteria. The students' activity criterion that was less active indicated that the developed model had not fulfilled the prescribed practicality aspect. These were the specific situations that students showed in learning.

- In answering the questions in concept tracking phase, students were still hesitant about their answers for fear of mistakes so that they often asked the teacher. This caused the allocated time wasted more. 
- Not every student was accustomed to discussing to solve open problems, so that there were some students only wrote the answers without giving ideas, some even chatted.

In the second trial, the average of students' activity was 2.80 . It meant that students' activity was included in active criteria. Nevertheless, there was still one activity that got score less than 2.5, namely on the activity of asking or commenting when discussing the result of the group presenters' answers. It showed that students' activity in term of asking and commenting still needed to be improved. Thus, improvement needed to be done so that the social system could run well. The improvement made was to provide input to partner teacher how to develop social system in learning in the classroom.

\section{c. Students' Response}

Students' responses both in trial I and in trial II were all positive. It indicated that students were happy with the PMT model used in the lesson.

\section{d. Learning outcomes}

In the first trial, only 19 percent of students achieved a minimum learning outcome of 75 . It indicated the effectiveness of the model seen from students' learning outcomes had not met the desired criteria. In trial II $75 \%$ of students got learning outcomes above 75 . It meant the effectiveness of the model seen from students' learning outcomes had met the desired criteria.

\section{e. Students' Creativity}

In trial I only $25 \%$ of creativity was in the high category. It meant that the classical creativity of students was still in "low" category. It indicated, the effectiveness of the model seen from students' creativity still did not meet the desired criteria. In trial II $62.5 \%$ of all students were in high category. It indicated, students' creativity still needed to be improved again so that the effectiveness of the model seen from the students' creativity was fulfilled.

\section{Advantages of PMT Model}

The advantages of the PMT model were: (1) to familiarize students with the concept tracking, (2) to familiarize students in solving problems with more than one answer, and (3) to familiarize students in solving problems in more than one way. The other advantages possessed by the PMT Model were: (4) to familiarize students to cooperate and discuss in solving problems and (5) to familiarize students to be brave to present the result in front of the class.

\section{Conclusion}

The process of PMT model development is based on the theory of development of Plomp (2007), which consists of three phases, namely: (1) preliminary research, (2) prototyping phase, and (3) assessment phase. The development result of this study is an open problem solving math learning model that can develop students' creativity (PMT Model), which meets valid, practical, and effective criteria. The validity criteria of PMT model got a score of 3.21 , which means the model is in valid category. PMT model that has been declared valid by the validator, then conducted a trial to determine the practicality and effectiveness. In trial III, the criteria of practicality and effectiveness have been fulfilled. 


\section{Suggestions}

1. The trial results show that the implementation of PMT Model can develop students' creativity, so PMT Model can be implemented by mathematics teachers in order to develop their students' creativity. Learning instruments produced in this development can be used as a source of learning by math teachers who want to develop students' creativity. In implementing PMT model, it is expected that the teachers do not directly answer the student's questions but ask the inverse questions that lead the students to the problem they are proposing.

2. In this research, the researcher did not develop instruments specifically for the components of social systems and reaction principles. Thus, for those who are interested in conducting further research on this model, it is necessary to develop instruments specifically for the components of the social system and the reaction principle instrument so as to obtain a clearer picture of both components.

\section{Disclosure statement}

No potential conflict of interest was reported by the authors.

\section{Notes on contributors}

Ketut Suastika - University of Kanjuruhan Malang, Indonesia.

\section{References}

Forrester, J.C. 2008. Thinking Creatively ; Thinking Critically. Asian Social Science, 4 (5): 100-105,

Hashimoto, Y. 1997. The Method of Fostering Creativity Through Mathematical Problem Solving. International Reviews on Mathematical Education,3 (29): 86-87

Izzati, N. 2009. Berpikir Kreatif dan Kemampuan Pemecahan Masalah Matematis: Apa, Mengapa, dan Bagaimana Mengembangkannya Pada Peserta Didik. Prosiding Seminar Nasional Matematika dan Pendidikan Matematika, Bandung 19 Desember 2009, hal: 49-60,

Joyce, B., Weil, M., \& Calhoun, E. 2009. Models of Teaching, Eighth Edition. Boston : Allyn and Bacon.

Kontoyianni, K., Kattou, M., Pitta-Pantazi, D.\& Christou, C. 2013. Integrating mathematical abilities and creativity in the assessment of mathematical giftedness. Psychological Test and Assessment Modeling: 55 (3): 289-315.

Mann, E. L. 2009. The Search for Mathematical Creativity: Identifying Creative Potential in Middle School Students. Creativity Research Journal. 21(4), 338-348.

Monahan, T. 2002. The Do-It-Yourself Lobotomy: Open Your Mind to Greater Creative Thinking. New York: Published by John Wiley \& Sons, Inc.,

Nadjafikhah, M., Yaftian, N., Bakhshalizadeh, S. 2012. Mathematical Creativity : Some Definitions and Characteristic. Procedia - Social and Behavioral Sciences. 31 (2012): 285 - 291.

NCTM. 2000. Priciples and Standards for School Mathematics. Copyright by the National Council of Teachers of Mathematics, Inc. 1906 Association Drive, Reston, VA 20191-9988.

Neeveen., N., Folmer, E. 2007. Educational Design Research. Dalam Plomp, T.\&Neeven, N. (Eds), Formative Evaluation in Educational Design Research. Proceedings of the seminar conducted at the East China Normal University, Shanghai (PR China), November 23 - 26, 2007.

Paparan Wamendikbud Bidang Pendidikan: Konsep dan Implementasi Kurikulum 2013. 
Pehkonen, E. 2007. Problem Solving in Mathematics Education in Finland. Finland: University of Helsinki Finland.

Permendikbud no 65 tahun 2013 tentang Standar Proses Pendidikan Dasar dan Menengah.

Plomp, T. 2007. Educational Design Research. Dalam Plomp, T.\&Neeven, N. (Eds), Educational Design Research: An Introduction. Proceedings of the seminar conducted at the East China Normal University, Shanghai (PR China), November 23 - 26, 2007.

Sharp, C. 2004. Developing young children's creativity: what can we learn from research?

Siswono, T.E.Y. 2007. Pembelajaran Matematika Humanistik yang Mengembangkan Kreativitas Siswa. Makalah disampaikan pada Seminar Nasional Pendidikan Matematika "Pembelajaran Matematika yang Memanusiakan Manusia" di Program Studi Pendidikan Matematika FKIP Universitas Sanata Dharma. Yogyakarta, 29-30 Agustus 2007.

Stenberg, R. 2006. The Nature of Creativity. Creativity Research Journal. 18(1): 87-98. 